\title{
The Analysis of the Central Kalimantan Tourism Development Plan Based on Ecotourism Policy Perspective
}

\author{
Bhayu Rhama ${ }^{1}$
}

\begin{abstract}
Ecotourism globally has become an alternative to mass tourism to minimize environmental impacts, and at the same time, it is also useful to improve the living standards of local communities. The Central Kalimantan government also underpin ecotourism activities as a tourism focus and written it on its regional regulations. This study is a literature study to analyse RIPPARPROV (Rencana Induk Pengembangan Pariwisata Provinsi/Provincial Tourism Development Master Plan) of Central Kalimantan 2013-2028 with a conceptual approach from Hall and Jenkins by looking at how clearly the desired policy issues are set forth in regulations. The method of analysis uses qualitative-comparative methods, by exploring the main themes of the global concept of ecotourism (which are ecotourism definition, ecology, education, responsibility, awareness of conservation and economy of local communities) in the RIPPARPROV of Central Kalimantan 2013-2028. The results of the analysis show that the Central Kalimantan Provincial Government is still premature in an effort to develop ecotourism in its territory. This is indicated by the lack of explanation about ecotourism specifically the absence of a policy on tourist education, awareness and conservation participation by tourists. There is only a policy of improving the local economy which is very prominent in Central Kalimantan's RIPPARPROV.
\end{abstract}

\section{Keywords:}

ecotourism; tourism plan; policy analysis; local regulations

\section{Introduction}

Indonesia is a country that has great potential for developing ecotourism because has more than 17 thousand islands, with ecologically unique positions between the continents of Asia and Australia and the Indian and Pacific Oceans. Moreover, Indonesia has around 237 million inhabitants with more than 300 ethnic groups and 742 regional languages and dialects (Nirwandar, 2015).

The development of ecotourism in Indonesia began in 1995, four years after The Ecotourism Society (TES) was established in the United States. The moment in 1995 was marked by a seminar and ecotourism workshop conducted by a non-government organization for environment namely WALHI (Wahana Lingkungan Hidup Indonesia/Living Environment Facility Organisation) and PactIndonesia in Bogor (Dalem, 2002). In this era, the government only saw that ecotourism was only one form of alternative minority tourism and did not deliver many tourist visits. Thus, mass tourism is still the government's focus, and tourism policy is continued based on spontaneous to attract visitor numbers (Cochrane, 2009).

However, the concept of sustainable development that emphasizes nature and people emerge and to be known globally.

\footnotetext{
${ }^{1}$ Department of Public Administration, University of Palangka Raya.

Email: bhayurhama@fisip.upr.ac.id
} 
Indonesia is also one of the countries that participated in implementing the concept, and its tourism development follows the principles of sustainable development. Therefore, in 2005, the government decided that tourism development in Indonesia must be based on holistic environmental protection and preservation principles by establishing the 2005-2025 National Development Plan.

Moreover, since 2005, tourist visits to Indonesia started to increase dramatically from year to year. A drastic increase in the number of tourists continues to occur from around 4-6 million to up to 14 million in 2017 that can be seen in Figure 1. Increasing tourist arrivals in Indonesia can be attributed to vigorous promotions along with the government's commitment to carry out sustainable tourism development. In a situation like this, ecotourism should be a discourse that is very commonly found in tourism policy in Indonesia.

However, it is not clear where the robust concept of ecotourism is in Indonesia's tourism policy. In 2011, the government issued Government Regulation No. 50 of 2011 concerning the Master Plan for National Tourism Development in 20102025/Rencana Induk Pembangunan Pariwisata Nasional (RIPPARNAS), unfortunately, none of ecotourism definition mentioned. As a result, it is not clear whether ecotourism is properly supported by the Indonesian government or not.

Nevertheless, the Government of Indonesia finally defines ecotourism as "natural tourism activities in the region that are responsible by taking into account the elements of education, understanding, and support for efforts to conserve natural resources, as well as increasing the income of local communities" (Article 1 number 1 Minister of Home Affairs Regulation No. 33 of 2009 concerning Guidelines Development of Ecotourism in the Region). The Government places ecotourism development into Regional Long Term Development Plan/ Rencana Pembangunan Jangka Panjang Daerah (RPJPD), Regional Medium Term Development Plan/Rencana Pembangunan Jangka Menengah

Figure 1.

The Development of Foreign Tourist to Indonesia

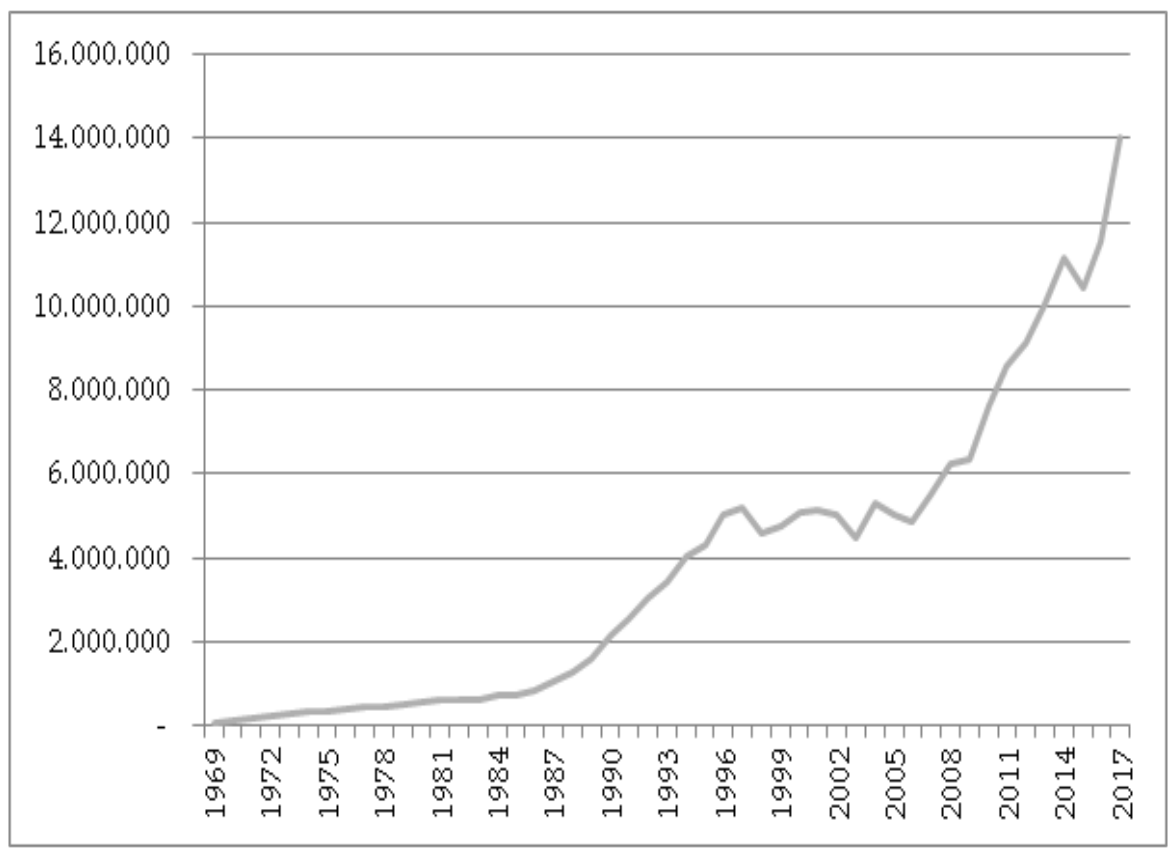

Source: BPS, 2018; Cochrane, 2009 
Daerah (RPJMD) and Local Government Work Plan/Rencana Kerja Pembangunan Daerah (RKPD) (Article 5 (1) Minister of Home Affairs Regulation No. 33 of 2009 concerning Guidelines for the Development of Ecotourism in the Regions).

Furthermore, it is also stated that ecotourism plans must be included in regional tourism planning (Article 5 (2)). The Master Plan for Provincial Tourism Development/ Rencana Induk Pembangunan Pariwisata Provinsi (RIPPARPROV) is a regional tourism planning at the provincial level which is derived from RIPPARNAS.

But indeed the Minister of Home Affairs Regulation No. 33 of 2009 was issued prior to RIPPARNAS made in 2011. Because RIPPARNAS' position is higher, namely the level of Government Regulation, then Article 5 (2) of Home Affairs Regulation No. 33 year 2009 means that the development of ecotourism is placed in RIPPARPROV as well as RPJPD, RPJMD, and RKPD. While ecotourism is not reflected in RIPPARNAS, but, there is still a hope that RIPPARPROV can include the concept of ecotourism, in accordance with Home Affairs Regulation No 33 year 2009, as well as the Province of Central Kalimantan's RIPPARPROV.

Central Kalimantan is one of four provinces in Borneo, Indonesia that has the least National Tourism Development Area/ Kawasan Pengembangan Pariwisata Nasional (KPPN) because The RIPPARNAS is actually consists of $222 \mathrm{KPPNs}$ in 33 provinces in Indonesia. But, only two KPPNs were given for the Central Kalimantan, Gorontalo, and South Sumatra province. The Province of West Sulawesi even only gets one KPPN.

The National Tourism Development Area/Kawasan Pengembangan Pariwisata Nasional itself is a national responsibility and focuses on the tourism area development. The small number of KPPNs in a province means that there is a lot of space for the regions to manage existing tourist destinations. The low number of KPPNs in Central Kalimantan and three other provinces open opportunities for local governments to manage various tourist destinations that exist as Provincial Tourism Destinations/ Destinasi Pariwisata Provinsi (DPP) or districts/ cities.

The national tourism development areas in Central Kalimantan are Tanjung Putting National Park and Sebangau National Park. It needs to be considered that the status of the national park area has consequences that tourism must be done in a limited way. Thus, ecotourism could be an alternative to deliver a win-win solution between conservation and recreation. Therefore, to support the development of the area, the Central Kalimantan Government has also issued ecotourism planning in the RIPPARPROV of Central Kalimantan. However, the question is, has the concept and strategy of ecotourism development been clearly defined into the document of RIPPARPROV Central Kalimantan?

Moreover, there are not many studies in Indonesia that have the objective to review local regulations on ecotourism policy related to a tourism development program in Indonesia. Several previous studies in Indonesia mostly analysed ecotourism from the perspective of ecotourism implementation but not from the perspective of policies that is issued as regional regulations (e.g. Erwiantono, Susilo, Aditya, Saleha, \& Budiayu, 2017; Harahap \& Baiquni, 2015; Ross \& Wall, 1999a; Ross \& Wall, 2001).

Therefore, the purpose of this study was to analyse the ecotourism policy in RIPPARPROV at one of the provinces above, namely the Province of Central Kalimantan. The province of Central Kalimantan was chosen because of its vast ecotourism potential as stated above. The Central Kalimantan is not a new province, unlike Gorontalo and West Sulawesi but it has long history in the development of Indonesia. In addition, the Central Kalimantan also has a large area and is largely peat swamp forest with 
high biodiversity, in contrast to South Sumatra.

This study will report the contents of the ecotourism policy as well as its analysis and its consequences for the development of ecotourism in Central Kalimantan. Before carrying out the analysis, it is necessary to establish some supporting literature in order to build a comprehensive ecotourism analysis foundation that will be discussed further in the next section.

\section{Literature Review}

The notion of sustainable tourism development emerged in 1987 in the Brundtland Report by the World Life Issues on Environment and Development/WCED (Obenaus, 2005). It is defined as 'the protection and preservation of a regional ecology in order to maintain the long term benefits' (Theobald, 2012, p. 76). This concept is present along with the development of human understanding of development which initially only refers to economic growth into another aspects includes social, cultural, political and specifically environmental aspect (which is considered important) because it is ultimately bring explicit formulation of sustainable development to compare to other alternatives mass tourism (Sharpley, 2009). In addition, the environment remains a major tourism capital that supports the success of tourism because if the environment is not well maintained and without making it sustainable, tourism will become a short-lived industry, leaving problems for other sectors.

Oneimportant sub-category of sustainable tourism development is ecotourism (Sharpley, 2009 , p. xii). Even though the definition of ecotourism is still debatable, but in general it is a form of applying the concept of sustainable tourism development to natural tourism. Nevertheless, the character of ecotourism is then determined by the experience of tourists in consuming nature (Sharpley, 2006, p. 4).

The study conducted by Sharpley (2006, p. 2) also shows that ecotourism shows a rapid increase in volume and value globally. In 2007, ecotourism accounted for $7 \%$ of the world travel market and was estimated at 25\% in 2012 (Crest, 2010; Hoag, 2007; Shum, 2007). Meanwhile, ecotourism also contributes to around $20-40 \%$ of international tourism in the world (STCRC, 2009, p. 13). For the AsiaPacific region, at least $10 \%$ of tourism income in 1993 came from ecotourism (Pratt, Rivera, Bien and Bertrand, 2011; Dalem, 2002). The rate of increase in ecotourism in 2004 was even three times faster than the entire tourism industry (Paulus, 2009; TIES, 2006). In addition, awareness of tourists towards the environment also increased as evidenced in 2009 where onethird of tourists prefer to stay in hotels that are environmentally friendly (Crawford, Mulvey and Quinn, 2009, p. 9).

Another study from Ianniello (2013) delivers additional information that ecotourism is also considered as a tourist destination desired by $20 \%$ of adolescents and since its emergence in the 1980s, the ecotourism has been being alternative tourism that can replace mass tourism (McLaughlin, 2011, p. 1). Even so, the cost of conducting ecotourism is relatively more expensive than mass tourism so that only $1 \%$ of total tourists successfully do ecotourism activity, and this has not changed in the last 13 years (Ianniello, 2013).

Therefore, the government is trying to find a way to reduce the ecotourism costs so that tourists can continue to arrive, and at the same time, nature conservation can be well maintained that is in accordance with the concept of ecotourism (Cengiz and Caliskan, 2009). Furthermore, the study by Serra (2007, p. 41) even suggested the notion that ecotourism activities are not only regulated by the government but must also be regulated by independent bodies that coordinate with each other. Therefore, a number of regulations for tourists need to be made to be obeyed and keep ecotourism in line with the initial concept that supports sustainable tourism (Sharpley, 
2006, p. 7). This means shifting ecotourism from maximizing short-term profits to developing long-term assets, especially on environmental assets (Serra, 2007, p. 7).

Meanwhile, several researchers suggest that ecotourism is nothing but a form of ecological politics which balances tourism fundamentalism and environmental conservationism. If this is done successfully, the benefits obtained are not only benefits for investors, but also local residents and the preservation of diversity and ecology (Var, Yalcinap, and Pulatkan, 2010; Ross and Wall, 1999). For example, residents can switch from environmental destroyers to environmental conservation agents by shifting their livelihoods from extracting natural resources to sustainable management of natural resources (Ramchurjee and Suresha, 2013, p. 93). This condition, although not always, can increase income for local people (Paulus, 2009, p. 4) and should be able to be a complement for the local economy (Serra, 2007, p. 43). However, preservation of wildlife may be half-hearted if conservationists do not have enough funds to feed animals whose habitat is getting lesser. Through ecotourism, conservationists can look after the flora or feed the endemic animals so that their sustainability becomes more secure.

Other potential benefits of ecotourism can also be political benefits related to the emergence of legislation about the environment, banning illegal hunting, habitat preservation, or environmental education (Paulus, 2009, p. 4). This is important because many countries still do not have a clear, sustainable and efficient conservation strategy for managing tourism and the environment (Serra, 2007, p. 36).

Apart from political perspective, another suggestion regarding ecotourism definitions has also been found in several kinds of literature. For example, Fennell and Weaver (1997) define ecotourism as tourism that emphasizes non-consumer appreciation of the natural attractiveness carried out in the capacity to bring local socio-economic communities. Meanwhile, Oladi and Bozorgnia (2010) see it as just a trip to a natural area to enjoy the natural attraction and to understand the culture of the local community. Moreover, Ogato et al. (2014) define ecotourism as a form of responsible tourism in the sense of preserving the environment while improving the welfare of local communities. Another study from Islam (2013) defines ecotourism as ecologically friendly tourism trips, coming to a natural environment that is not damaged, and accompanied by understanding its environment, culture, preservation, and economic activities.

Another definition of ecotourism from the perspective of government can be seen from the Government of Indonesia. Through the Ministry of Home Affairs, Indonesia Government defines ecotourism "a natural tourism activity in the area that is responsible by taking into account the elements of education, understanding, and support for efforts to conserve natural resources, as well as increasing the income of local communities" (Article 1 number 1 Minister of Home Affairs Regulation No 33 of 2009 concerning Guidelines for the Development of Ecotourism in Regions). This definition is best suited to the definition of ecotourism by Fennell and Weaver (1997) but is more specific by showing how the form of nonconsumer appreciation is intended, namely in the form of education, understanding, and support for conservation. Due to the needs of this recent study that analyses the government ecotourism policy, therefore the definition used is the definition held by the government that in line with the ecotourism practice definition.

Based on the definition of ecotourism above, 'responsible' is one of the key aspects in the concept of ecotourism. This aspect distinguishes ecotourism from "eco-pirates," which are tourism products that merely copy sustainable tourism products but are not responsible, characterized by low costs, inferior experiences, and have adverse environmental and social impacts (Scheyvens, 1999). 
Even though the appropriate ecotourism is responsible with the environment, however, Blamey (2001) criticizes that even the most stringent ecotourism will have a negative impact on the environment. The reason is because the growth of ecotourism means a growing number of tourists who come to a destination that is still pristine. Therefore, for ecotourism to be truly responsible, there must be careful planning and management efforts (Wall, 1997). For example, Boyd and Butler (1996) developed an ecotourism management framework that offers three management models namely eco-specialist, middle, and eco-generalist. In line with this, an ecotourism certification discourse was raised but still stumbles on the issue of who is responsible as the top authority, what institutions have the right to play, and what 'natural' experience is ideally offered (Jamal et al., 2006).

A previous study from Perera and Vlosky (2013) found that the quality of visits, previous visits, satisfaction, and perceived value play a role in encouraging tourists to come to ecotourism destinations. Moreover, tourist environmental awareness also plays a role in encouraging visits to ecotourism destinations (Del Chiappa and Lorenzo-Romero, 2014), while, other psychological aspects that are known to encourage visits to ecotourism destinations are self-construction, willingness to pay more, and ecological beliefs (Hwang and Lee, 2018).

Implicitly, based on the above discussions, the global development of ecotourism in the end always focuses on the issue of the definition of ecotourism, how ecotourism can maintain ecology, how tourism is responsible for the environment, education, understanding the environment, and last but not least, how ecotourism can support, conservation and the economy of local communities.

Therefore, ecotourism activities (with all definitions and all aspects related to ecotourism above) should be clearly written in a public policy that binds the government and society so that the concepts and objectives of ecotourism development can be measured and assessed by all parties. This statement is supported by Tjiptoherijanto (2012) who said that one of the benefits of issuing public policies is to develop a specific discourse (such as an ecotourism discourse) so it can be in accordance with the intended goals and objectives.

In addition, Dror (2017) also argues that public policy is a series of actions/ activities to achieve the intended public need by delivering strategy to overcome specific obstacles (difficulties) and use possibilities (opportunities) proposed by a person, group, or government in a particular environment, so it needs to be clearly stated. A similar opinion about public policy was also revealed by Dunn (2015) in his study which stated that public policy is a series of activities that have certain intentions/objectives that are followed and carried out by an actor or group of actors related to a problem or something that is considered. Therefore, it can be understood that public policy is a response to circumstances to regulate and overcome certain problems and objectives which must be clearly announced.

Furthermore, Hall and Jenkins (2003) in their study said that how serious the policies made could be evaluated simply by seeing how clearly the content of the policy was delivered in script or regulations made by the government. This should also apply to the ecotourism policy discourse that must be clearly stated (written) in the tourism regulations established by the Central Kalimantan Government (namely RIPPARPROV of Central Kalimantan) if ecotourism activities is an important sector in developing sustainable tourism in Central Kalimantan Province. In other words, the government policy about ecotourism development must certainly be read in the RIPPARPROV of Central Kalimantan and be understood by all parties

Based on the discussion above, the discourse analysis of ecotourism in regional 
regulations on tourism can be carried out with systematic research which is explained further in the section below.

\section{Method}

This study is an atypical case study that carries out analysis of ecotourism policy in the RIPPARPROV (provincial development tourism master plan) of Central Kalimantan 2013-2028, with regard to the relevance of the development of ecotourism globally. Thus, this study shows a comparison between the ecotourism policies owned by the Central Kalimantan Government and the ecotourism practices so that weaknesses, gaps, and the need for developing ecotourism policies can be identified. In addition, an evaluation of the RIPPARPROV of Central Kalimantan 2013-2028 policy has never been done so that the results of this study can deliver benefits to the Central Kalimantan provincial government (as policy makers) to take steps that can accommodate the development of ecotourism activities in the present as well as the future.

Therefore, this study conducts a literature study by collecting secondary data about ecotourism from the Ministry of Tourism of the Republic of Indonesia and other sources including books, journals, research report and websites that are relevant to the developing ecotourism globally, which are, (i) ecotourism definition, (ii) ecology, (iii) education, (iv) responsibility, (v) understanding and support for conservation, and (vi) the economy of local communities. Those key issues then are used as the instruments to analyse the content of the RIPPARPROV of Central Kalimantan documents (along with its attachments and explanations), in accordance with the definition of ecotourism adopted by the Indonesian government that has a further explanation as for the discussion and findings in the following sections. In addition, NVivo software is used for the data analysis approach so that the content in RIPPARPROV of Central Kalimantan can be explored and understood in more depth.

\section{Result and Discussion The RIPPARPROV of Central Kalimantan}

Tourism has been started to be a focus of sustainable development at global and regional levels, including in Indonesia. However, tourism development in Indonesia, which requires the involvement of many parties, is widely developed sporadically and spontaneously follows the perceptions of tourists (Cochrane, 2009; Rhama, 2017). Therefore, as the solution, the Government of the Republic of Indonesia has made a guidance for develop tourism by establish the Law No. 10 of 2009 concerning Tourism, which is then followed by PP No. 50 of 2011 concerning a tourism master plan for a period of 15 years known as RIPPARNAS 2010-2025 (National tourism development master plan) to clarify the direction of tourism development in Indonesia. Thus, all regional government regions in Indonesia (including the Central Kalimantan Provincial Government) must also create a master plan for tourism development in their respective administrative areas.

The RIPPARPROV (provincial tourism development master plan/Rencana Induk Pembangunan Pariwisata Provinsi) of Central Kalimantan was formulated in 2013 through Regional Regulation No. 2 of 2013 concerning RIPPARPROV Central Kalimantan 2013-2028. This document consists of 66 articles, two attachments, and one explanation. The two attachments of RIPPARPROV are the DPP Region (Provincial Tourism Destinations) and details of indications of the Central Kalimantan provincial tourism development program in the 2013-2028 period. This policy divides the DPP into three major regions, namely the Western Region, the Central Region, and the Eastern Region.

The vision of tourism development in Central Kalimantan was formulated as "the realization of Central Kalimantan as a quality, 
organized and environmentally wide-ranging tourist destination for the welfare of society" (Article 4 (4)). The mission to realize this vision includes (Article 4 (5)):

a. Making Central Kalimantan Province as a national tourist destination;

b. Making Central Kalimantan Province as a tourist destination that is always remembered and loved by tourists;

c. Giving life and livelihood to the people of Central Kalimantan from the tourism sector;

d. Expand business opportunities and employment in the tourism sector.

e. Encourage the creation of a tourism-based creative economy;

f. Making tourism activities the activities of the community and the government as catalysts, regulators, and facilitators;

g. Maintain sustainability and foster a sense of love for nature and culture; and

h. Maintain local religious and cultural values.

The RIPPARPROV of Central Kalimantan holds the principle of developing its tourist attraction in the form of a balance principle between efforts to develop destination management to create quality and competitive attractiveness, with the development of conservation efforts to preserve and sustain the tourism resources (Article 12). The Central Kalimantan Government then divided RIPPARPROV's plan into three stages: Stage I (2013-2017), Stage II (20182022), and Stage III (2023-2028) (Article 4 (7)). The provision of tourism support facilities is divided between the provincial government, district/city government, community, and the private (Article 21). The government also encourages investment by providing incentives, convenience and investment promotion in the tourism sector (Article 31). Tourism promotion itself is carried out locally and globally (Article 40).

\section{The Concept of Ecotourism in RIPPARPROV of Central Kalimantan}

The concept of ecotourism is the first key instrument in this recent research, and it shows no definition of ecotourism in the RIPPARPROV of Central Kalimantan, however, there is a word of ecotourism that appears in the policy explanation. This concept is referred to as "ecological tourism" which is defined as ecotourism or wild tourism (Explanation of Article 11 (1)). This concept is used to explain the types of tourist attraction mentioned in article 11 . There are three types of tourist attraction in article 11, namely natural tourist attraction, cultural tourist attraction, and manmade tourist attraction. The local government explained that these three types of attraction could be further developed into 19 types of tourism, one of which was ecotourism. This explanation contains inconsistencies because one form of tourism development is natural tourism, while nature tourism itself includes three types of tourism that will be developed. Apart from this inconsistency, it is interesting that ecotourism is not categorised as natural tourism, cultural tourism, or man-made tourism, but as a development category, shows that ecotourism is actually a combination of the three. But if it refers to the perspective of an ecological tour, then it will have a strong fundamental in natural tourism, as defined by the central government.

\section{The Policy of Ecotourism in RIPPARPROV of Central Kalimantan}

Based on the perspective that ecotourism is a form of destination development, thus, this concept should exist in the attachment of the development plan. Even so, there is no mention of the development of certain DPPs into ecological (as the second instrument) tourism destinations. This is different, for example, with other types of development, such as, the development of educational tourism which has an attachment that explains 
several destinations, namely Lake Tahai - Bukit Tangkiling and Tugu Soekarno in Palangka Raya City, one of the areas in the central region.

It is clearly stated that educational tourism, as the third key instrument, is given to the western and central regions (Article 24). But this reference brings back inconsistency because, in the detailed plan, there is no western region that gets development into educational tourism. Furthermore, there is no explanation on how the form of educational tourism in the area of Lake Tahai - Bukit Tangkiling and Tugu Soekarno in the City of Palangka Raya. This could be just a history of education rather than ecological education, because the Soekarno Monument in this area, has only a historical value but has nothing to do with natural tourism.

The fourth instrument of ecotourism is responsibility gets enough consideration in RIPPARPROV indicated by the ratio of a special article, namely article 58, which regulates the development of responsibility for the environment. There are two provisions made by this article, namely (1) the development of the tourism industry must maintain environmental sustainability in accordance with the legislation in force, and (2) the tourism industry that can cause environmental pollution must carry out environmental management in accordance with the legislation applies. If viewed from this article, then the aspect of responsibility is only charged to the management agency, not to tourists whereas responsibility in the context of ecotourism is spread not only to managers but also to the people and tourists. Even for this matter, there is no program specifically directed to oversee the implementation of the responsibilities that exist for the destination manager.

Meanwhile, the concept of understanding and support for conservation (as the fifth instrument) that quite important for ecotourism is also not found in the document. This keyword exists, namely in article 30 (3) point ' $a$ ' which states that there is an effort to "improve understanding, support, and community participation in realizing the Sapta Pesona (a concept of seven elements of development and management of tourist attraction in Indonesia) for the creation of a conducive climate for local tourism". Understanding and support in this context are not towards conservation but against Sapta Pesona. Sapta Pesona is a tourism concept that was first initiated in 1989 through the Decree of the Minister of Tourism, Post and Telecommunications No. 5 of 1989 concerning Guidelines for Organizing Enchantment of Sapta Pesona. Therefore, Sapta Pesona is defined as "conditions that must be realized in order to attract tourists to visit an area or region in the country of Indonesia." This condition is safe, orderly, clean, cool, beautiful, friendly and memorable. Clean and cool aspects can refer to conservation but it is clearly not perfect because cleanliness and coolness can also be realized without conservation, for example by disposing of garbage in a place without the principle of environmental sustainability to the extent not seen by tourists, or bringing imported species such as trees as shades, rather than conserving endemic local plants. In addition, this awareness and support are only imposed on the community, not on tourists, in contrast to the concept of appropriate ecotourism.

However, conservation has a broader space in the policy. It is one of the considerations in the formulation of RIPPARPROV (the consideration section), being one of the principles of tourism (Article 2), one of the mission and objectives of tourism development (Article 4 (5)), tourism development targets (Article 4 (8)), direction of tourism development (Article 4 (9)), and also become one of the two parts in the principle of balance in the development of tourist attraction (Article 12). Conservation is carried out in the effort of development, stabilization, and revitalization of a tourist attraction (Article 13). Conservation is also one of the six lines of general tourism development 
policy in Central Kalimantan (Article 42). Environmental sustainability is required for the development of the tourism industry as a form of environmental responsibility (Article 58). The conservation program is quite a lot to be mentioned in the programs planned for the construction of provincial tourism destinations. This is mainly manifested in the form of planting trees in tourist destinations throughout the destination, creating standards and guidelines for environmental management in the implementation of tourism businesses, giving strict sanctions for those who violate environmental management regulations, and maintenance of the environment and destination areas and surroundings. This is supported by the involvement of SKPD (local government agencies) who are responsible for the environment as one of their responsibility program. Indeed, as a whole, the goal of carrying out conservation is in the hands of the government, the private sector and the community, but, none mentioned that is also the tourists' responsibility.

Meanwhile, the goal for increasing the income of local people, that implicitly shows the urgency of local community's economy (the sixth key instrument), is only being facilitated in one article in this policy. Article 30 (2) point ' $b$ ' states that the government develops regulations that are oriented to encourage the development of the economic business of local communities in the tourism sector. Many times the community is referred to as an important party in this policy, but only one is specified in the local community. Even so, in the programs that emerged, there was an orientation towards strong local economic development efforts. These forms include the development of culinary and the shopping areas of traditional products of Central Kalimantan, tourism-aware counseling for local transportation service providers (taxi bike, taxi, 'klotok', speedboats, etc.), and so on. In fact, in the details of indications of tourism destination development programs, the first and second programs are specifically directed at the local community. This program has several goals, which are: (i) increase community participation in the field of tourism that is consisting by eight activities, and (ii) increase the impact of tourism on the community, that is consisting by five activities. The 13th program is also directed at local communities, namely the use of local resources (human resources and other resources) in organizing tourism businesses. Likewise, the 15th program, namely the provision of incentives for the tourism industry that uses local products and products of micro, small and medium enterprises.

Therefore, compared to the definition given by the central government through the Ministry of Home Affairs, the RIPPARPROV of Central Kalimantan is still very premature in developing ecotourism policies. However, compared to the definitions of Fennell and Weaver (1997), that ecotourism is emphasizing non-consumptive appreciation of natural attractiveness carried out in the capacity to bring socio-economic to local communities, in fact, RIPPARPROV of Central Kalimantan has more addressed on ecotourism issues. This is demonstrated by the existence of conservation efforts and adjusting to the capacity to bring local socio-economic communities through various training and programs and activities. But still, the aspect of appreciation that leads to tourists has no effort to make tourists appreciate the natural attraction through their non-consumptive behavior. In addition, the definitions of Oladi and Bozorgnia (2010) and Islam (2013) can easily be fulfilled because this definition merely looks at ecotourism as a form of natural tourism that also weighs local culture. It can be found in RIPPARPROV of Central Kalimantan if local culture strives as part of a tourist attraction, namely cultural attraction. Unfortunately, this research is based on the ecotourism definition of the central government of Indonesia, and therefore, the 
ecotourism policy in RIPPARPROV of Central Kalimantan is still classified as partial and does not really reflect the ecotourism intended by the central government or Fennell and Weaver (1997) and neither Ogato et al. (2014).

\section{Conclusion}

The discussion above shows that the ecotourism policy in RIPPARPROV of Central Kalimantan is in the premature condition or implicitly exist. The RIPPARPROV only states that ecotourism is a form of development of the three existing tourism categories namely natural tourism, cultural tourism, and man-made tourism but without further explanation. Therefore, it is clearly seen that there is no indication that certain destinations will underpin the ecotourism development. Moreover, the characteristics of ecotourism are not fully indicated in the development policy in RIPPARPROV. It only defines ecotourism as "natural tourism activities in the area that is responsible by paying attention to the elements of education, understanding, and support for efforts to conserve natural resources, as well as increasing the income of local communities." This definition emphasizes the importance of education, understanding, and support for conservation not only by the government, the private sector, and the community but also by tourists. But none of the efforts about improving education, understanding, and support for conservation pointed at the tourists. The education, understanding, and support are only directed at the government, the private sector, and local communities while tourists have not been given the same thing. There is only one indication that the provincial government is providing education for tourists, but it is likely that this is only in the form of historical education, not conservation education. Neither in-depth clarification is also not found in the document. Only the support for the local economy is really encouraged in this policy, thus, making the ecotourism aspect implicitly emerge in RIPPARPROV of Central Kalimantan, but still partial to economic aspects, not conservation aspect. In the future, it is necessary to formulate policies that also accommodate efforts to educate, provide understanding, and invite tourists to support conservation efforts that have actually been promoted on the government, private, and community sides in the province.

\section{References}

Blamey, R., K. (2001). Principles of Ecotourism. In D. B. Weaver (Ed.). The Encyclopedia of Ecotourism. Oxon, UK: CABI Publishing.

Boyd, S. W., \& Butler, R. W. (1996). Managing ecotourism: An opportunity spectrum approach. Tourism Management, 17(8), 557566. doi: 10.1016/s0261-5177(96)00076-3

BPS. (2018). Kunjungan wisatawan mancanegara berdasarkan tahun. Jakarta: BPS.

Oladi, J., \& Bozorgnia, D. (2010). Evaluating the ecotourism potentials of Naharkhoran area in Gorgan using remote sensing and geographic information system. Earth Resources and Environmental Remote Sensing/ GIS Applications. doi:10.1117/12.860095

Cengiz, T., \& Çaliskan, E. (2009). Ecological approach in sustainable tourism: Savsat district example. Sci. Res. Essay, 4(5), 509520.

Cochrane, J. (2009). New directions in Indonesian ecotourism. Tourism in Southeast Asia: Challenges and New Directions, 254-269.

Crawford, J., Mulvey, M, Quinn, S. (2012). Ecotourism handbook for Ireland. Dublin: Failte Ireland.

CREST. (2010). Responsible Travel: Global Trends \& Statistics. Stanford University \& Washington, DC.

Dalem, A. A. G. R. (2002). Ecotourism in Indonesia: Linking Green Productivity to Ecotourism: Experiences in the Asia-Pacific Region. Tokyo: Asian Productivity Organization.

Del Chiappa, G., \& Lorenzo-Romero, C. (2014). Environmental issues to profile the 
consumers' attitude: a latent segmentation approach. Environmental Engineering and Management Journal, 13(10), 2449-2457.

Decree of the Minister of Tourism, Post and Telecommunications No. 5 of 1989 concerning Guidelines for Organizing Enchantment of Sapta Pesona. Jakarta: Departemen Pariwisata, Pos, dan Telekomunikasi.

Dror, Y. (2017). Public policy making reexamined. Routledge.

Dunn, W., N. (2015). Public policy analysis. Routledge.

Erwiantono, E., Susilo, H., Aditya, A., Saleha, Q., \& Budiayu, A. (2017). Analisis kebijakan untuk pengembangan ekowisata berkelanjutan di kawasan perairan Labuan Cermin-Kabupaten Berau, Kalimantan Timur. Jurnal Kebijakan Sosial Ekonomi Kelautan dan Perikanan, 6(1), 47-63.

Fennell, D. A., \& Weaver, D. B. (1997). Vacation farms and ecotourism in Saskatchewan, Canada. Journal of Rural Studies, 13(4), 467475.

Hall, C. M., \& Jenkins, J. M. (2003). Tourism and public policy. Cengage Learning EMEA.

Harahap, S. A., \& Baiquni, M. (2015). Kebijakan Pengelolaan Ekowisata Taman Nasional Terkait Otonomi Daerah Taman Nasional Komodo Di Kabupaten Manggarai Barat (unpublished dissertation). Yogyakarta: Universitas Gadjah Mada.

Hoag, H. (2007, June 23). Green to go. The Globe and Mail. Retrieved November 1, 2018, from http://www.theglobeandmail.com/life/ green-to-go/article4095237/?page=all

Hwang, K., \& Lee, J. (2018). Antecedents and consequences of ecotourism behavior: independent and interdependent selfconstruals, ecological belief, willingness to pay for ecotourism services and satisfaction with life. Sustainability, 10(3), 789.

Ianniello, J. (2013). Ecotourism Remains a Dream for Too Many. Roy Morgan Research.
Islam, M. U. (2013). Prospective of ecotourism in Poonch District. International Journal of Physical and Social Sciences, 3(12), 541.

Jamal, T., Borges, M., \& Stronza, A. (2006). The institutionalisation of ecotourism: Certification, cultural equity and praxis. Journal of Ecotourism, 5(3), 145-175.

Minister of Home Affairs Regulation No. 33 of 2009 concerning Guidelines Development of Ecotourism in the Region. Jakarta: Minister of Home Affairs.

McLaughlin, J.M. (2011). Ecotourism Assessment: Applying the Principles of Ecotourism to Paddle-Based Recreation in St. Lawrence Islands National Park and Environs (unpublished thesis). Kingston: Queen's University.

Nirwandar, S. (2015). Ecotourism in Indonesia. Jakarta: Ministry of Tourism and Creative Economy.

Obenaus, S. (2005). Ecotourism - sustainable tourism in national parks and protected areas: A case study of Banff National Park in Canada and National Park Gesäuse in Austria - a comparison (unpublished dissertation). Austria: University of Vienna.

Ogato, G.S., Abdise, F., Gammie, T., \& Abebe, W. (2014). Promoting rural local development: The case of Wonchi ecotourism society, West Shoa Zone, Ethiopia. Prime Journal of Social Science, 3(4), 662-673.

Paulus, A. (2009). Impacts of Ecotourism on the Behaviour of Sulawesi Crested Black Macaques (Macaca nigra) and Spectral Tarsiers (Tarsius spectrum) in the Tangkoko-Batuangus Nature Reserve, North Sulawesi, Indonesia (unpublished dissertation \& thesis). Plymouth: The University of Plymouth.

Central Kalimantan Regional Regulation No. 2 of 2013 concerning RIPPARPROV Central Kalimantan 2013-2028. Palangka Raya: Pemerintah Daerah Kalimantan Tengah.

Government Regulation No. 50 of 2011 concerning the Master Plan for National Tourism Development in 2010-2025. Jakarta: Pemerintah RI. 
Perera, P., \& Vlosky, R. (2013). How Previous Visits Shape Trip Quality, Perceived Value, Satisfaction, and Future Behavioral Intentions: The Case of Forest-Based Ecotourism in Sri Lanka. International Journal of Sports Management, Recreation $\mathcal{E}$ Tourism, 11, 1-24. doi:10.5199/ijsmart-1791$874 x-11 a$

Pratt, L., Rivera, L., Bien, A., \& Bertrand, N. (2011). Tourism: Investing in energy and resource efficiency. Spain: UNWTO.

Ramchurjee, N, A., \& Suresha, S. (2013). Ecotourism in Bagalkot District, Karnataka, India: An assessment of the inhabitants' awareness level and attitudes. International Journal of Environmental Sciences, 3(6), 22782290.

Rhama, B. (2017). The implications of the values and behaviors of actors for ecotourism policy: A case study of Sebangau National Park, Central Kalimantan, Indonesia (unpublished dissertation). Lancashire: University of Central Lancashire.

Ross, S., \& Wall, G. (1999). Ecotourism: towards congruence between theory and practice. Tourism Management, 20, 123-132.

Ross, S., \& Wall, G. (1999a). Evaluating ecotourism: the case of North Sulawesi, Indonesia. Tourism Management, 20(6), 67368.

Ross, S., \& Wall, G. (2001.). Ecotourism: A theoretical framework and an Indonesian application. Tourism, Recreation, and Sustainability: Linking Culture and the Environment, 271-288. doi:10.1079/9780851995052.0271
Scheyvens, R. (1999). Ecotourism and the empowerment of local communities. Tourism Management, 20(2), 245-249.

Serra, G. (2007). Ecotourism in the Palmyra Desert, Syria: A Feasibility Study. BirdLife International.

Sharpley, R. (2006). Ecotourism: A consumption perspective. Journal of Ecotourism, 5(1-2), 7-22.

Sharpley, R. (2009). Tourism development and the environment: Beyond sustainability? London: Earthscan.

Shum, K. (2007). Trends in ecotourism. Retrieved November 1, 2018, from http://www.lohas. com/green-travel

STCRC. (2009). Wildlife tourism: Challenges, opportunities and managing the future. Australia:Sustainable Tourism Cooperative Research Centre.

Theobald, W. F. (2012). Global tourism. Routledge. TIES. (2006). Global ecotourism fact sheet. Washington.

Tjiptoherijanto, P. (2012). Civil Service Reform in Indonesia: Culture and Institution Issues. Depok: Department of Economics, Faculty of Economics, University of Indonesia.

Var, M., Yalcinap, E., Pulatkan, M. (2010). A potential offer-demand problem in ecotourism: Different perspectives from ecotourists and indigenous people. Scientific Research and Essays 5(17), 2517-252.

Wall, G. (1997). Is ecotourism sustainable? Environmental Management, 21(4), 483-491. 